\title{
Ranking and Assessment of the Efficiency of Social Media using the Fuzzy AHP-Z Number Model - Fuzzy MABAC
}

\section{Zoran Bobar ${ }^{1}$, Darko Božanić², Ksenija Djurić², Dragan Pamučar $^{2}$}

${ }^{1}$ Ministry of Defense of the Republic of Serbia, Bircaninova 5, 11000 Belgrade,

${ }^{2}$ Military Academy, University of Defence in Belgrade, Generala Pavla Jurisica Sturma 33, 11000 Belgrade, Serbia

emails: zoran.bobar@mod.gov.rs, darko.bozanic@va.mod.gov.rs, ksenija.djuric@mod.gov.rs,dragan.pamucar@va.mod.gov.rs

Abstract: Methods of ranking and evaluation of the effectiveness of Social Media (SM) given and applied in this paper are the basis for the selection of online media that the public administration uses when communicating with citizens. The methodology presented is based on multicircular decision-making using the Fuzzy Analytical Hierarchical Process (fuzzy AHP) - Z number model - Fuzzy Multi-Attributive Border Approximation Area Comparison (fuzzy MABAC), which eliminates the traditional intuitive ratings of $P R$ services. This resulted in poor use of available channels of communication or ineffective communication. Positive results of the application of presented methods are especially evident in increasing the number of channels of communication on the Internet and the realization of communication goals for greater participation of citizens in public administration.

Keywords: Internet; Social Media; Fuzzy Analytical Hierarchical Process (fuzzy AHP); Fuzzy Multi-Attributive Border Approximation Area Comparison (fuzzy MABAC); Z-number

\section{Introduction}

Governmental institutions, businesses and other legal entities are increasingly using social media as channels of communication with their target public. Until recently it was common practice to have PR tools located on the front page of the site in the form of news, multimedia, contacts, and links, serving as a convenient way of servicing classic media [1]. More recent research has revealed that the public is spending an increasing amount of time on social media, and that the potential of social media is based on interactions, collaboration and cooperation, 
where social media is seen to transform the relationship of public service and the citizenry [2]. In the process of communication with public, government institutions and businesses are not able to use the virtually unlimited number of media available on the Internet with equal efficiency. The selection of social media to be used as a communication channel ensuring reach amongst the targeted public online with desired efficiency is one of the challenges faced by these services in implementing a given communication strategy.

In line with the new trends in the usage of social media for business purposes, a series of studies have examined the justification of using social media in the communication of public administration with the citizenry. Some focused on functional availability [3], benefits and risks [4], and the impact of social media use [5]. The common trait found in all these studies is the analysis and assessment of multiple social media according to a single criterion, or the analysis and evaluation of a single social media based on multiple criteria. However, communicators are often confronted with the need to choose among available social media. They have to identify the criteria and the methodology for making such a choice to reduce the risk of failure in communicating via social media.

Considering the trends in social media usage and the perspective of involving such media in the activities of public administration as well as that of other organizations, the aim of this research is:

1. To define the general criteria for choosing social media for communication between government bodies and the target public; and

2. To develop the methodology for social media ranking in view of the selection of a particular communication channel suited to a communication strategy.

This paper examines the various options for rating and ranking social media by using parameters that influence the efficiency of communication, defined on the grounds of criteria partially used in the evaluation and ranking of social media, as well as on expert assessments of the applicability of such criteria.

\section{Review of Literature}

Although practically all state institutions have websites today, the needs of citizens using the Internet have not entirely been met. The emergence of Web 2.0 technology prompted the development of new public administration services for the implementation of eGov 2.0 or Social Government projects [6] [7] which enable an interactive dimension of public administration through online activities.

The approach most frequently used in the development of eGovernment is the evolutionary one. Namely, public administration portals evolve from a basic 
presence on the Internet, through interaction and then to collaboration with citizens [8]. Public relations through the web portal of the institution gradually evolve from one-way communication, i.e. from providing information on websites to the use of online services for two-way communication and connections with institutional sites and profiles on social media (Social Network Room). This implies a high-level of interaction with the target audience [9]. Social media enable greater participation of citizens and stakeholders, create a space for cooperation with government and stimulate innovation in the public sector [10]. For the public sector, communication through social media is more targeted, more economical and more efficient compared to other communication channels. If the information is available on social media, reactions can be expected quickly. Such feedback can help speed up more efficient decision-making and serve as a way of confirming public support. Feedback also reveals which media should be used as carriers of specific information in communicating with the public [11]. Citizens and public authorities have different expectations regarding the use of social media. Citizens expect their government to use social media as a tool which would give them a stronger voice in the decision-making process. Conversely, the administration sees social media as a tool for interacting with citizens, and a way of promoting services in line with current government policies and strategies. [12].

In using social media to communicate with citizens, the public sector pays insufficient attention to the "variants among social media tools, i.e., which tools are appropriate for certain activities and which for others". Although the adoption of new technologies is important, it is equally important to assess how these technologies are used and to which purpose. Some technologies are broadly used, but not with their full potential. The problem faced by the public sector is the excessive use of social media by employees, as this can generate problems in managing communications or ensuring that all communications are true and consistent [13].

\subsection{Review of Criteria for Evaluation of Social Media Efficiency}

The initial assumption of this paper was the fact that the use of social media is determined by a number of factors. Thus, the study recruited 35 researchers working in the field of public administration and public relations. Based on the evaluation of their competence, 11 experts were selected. Experts were polled in more than one round using the Delphi method. Criteria presented in the literature were offered to the experts, along with the possibility of adding new ones and eliminating the ones already offered. In this research further criteria for the assessment of SM efficiency in communication with society were proposed:

Criterion $1(\mathrm{Cl})$ : Functionality. Social media can be evaluated based on available tools classified into functional blocks: identity, conversation, sharing, presence, relationships, reputation and groups [14]. The classification of social media in 
relation to the availability of functional blocks enables us to look at different levels of presence on the Internet and networking, or how and to what level of availability can a given social medium be configured. The convenience of functional classification lies in the ability to compare existing social media and assess their capabilities in relation to the target audience.

Criterion 2 (C2): Presence. Social media can be present in a certain geographical area to a greater or lesser extent. If the targeted public is in that area, the influence of such presence on the selection of whether and to what extent these particular social media platforms be used is related to the share of the targeted public using that medium. Presence, measured by the number of users of the social network, also affects the level of reach of the targeted public, although it does not have to be directly proportional to the number of users of that platform. Quantitative data for this criterion are reliable and are found as statistical data for each social medium [15].

Criterion 3 (C3): Purpose. Social media can also be evaluated according to their purpose because the functional richness of a social medium is not sufficient to assess the effectiveness of that medium in relation to individual social groups. In general, once social media find their own community their true purpose is revealed. The information offered and the way of communicating are most often suited to a particular type of media. Kaplan et al. categorized social media by their purpose as follows: Collaborative Projects, Blogs and Microblogs, Content Communities, Social Networking Sites, Virtual Game Worlds, Virtual Social Worlds [16].

Criterion 4 (C4): Richness of content. The effectiveness of social media can also be viewed through the richness of media content described in Media Content Theory [17]. Modern public relations theory is based on two-way communication with the target audience, which implies the use of social media precisely because of its interactive nature. Social media research suggests the need to expand Media Content Theory, taking into account the phenomenon of social networking and communication efficiency achieved through massive networking and the collaboration of communicators through those media [18].

Criterion 5 (C5): Target audience. It is customary for the same target group to use several social media platforms. One of the ways in which the target audience is determined is to rely on available statistics of a social media platform or on relevant databases offering information on the use of social media. Media coverage and target audience do not need to be directly linked, and significant deviations in social media are possible. For example, although Facebook is used by more than $47.6 \%$ of the population of the Republic of Serbia, the percentage of those aged over 60 is only $10 \%$, and male population percentage is higher [19]. Therefore, the target audience on a social media platform must be segmented, in order to assess its suitability for communication with the public. 
Criterion 6 (C6): Engagement., Despite the functional availability of various tools of social media, the public recognizes some as more or less effective or credible regarding the content provided. Surveys covering social network users indicate multiple levels of engagement (liking, sharing, comments), which is directly related to the level of trust in that media [20].

Based on available literature and the positions agreed on by the expert group, an overview of the criteria that influence the choice of a social media platform for public administration communication with the citizens has been formed, as indicated in Table 1.

Table 1

Criterion - basic characteristics

\begin{tabular}{lllll}
\hline Criterion & Description & Type & Value trend & Range \\
\hline C1 & Functionality & Quantitative & Growing & 1 to 7 \\
\hline C2 & Presence & Quantitative & Growing & 1 to 5 \\
\hline C3 & Purpose & Qualitative & Growing & 1 to 5 \\
\hline C4 & Content richness & Qualitative & Growing & 1 to 5 \\
\hline C5 & Target audience & Quantitative & Growing & 1 to $100 \%$ \\
\hline C6 & Engagement & Qualitative & Growing & 1 to 5 \\
\hline
\end{tabular}

\section{Method Description}

A specific research method has been developed to evaluate and rank the effectiveness of social media. The model is defined based on examination of the literature related to selection of social media platforms and mulitple-criteria decision making implemented in other research fields. The authenticity of the criteria based on which the ranking is made, as well as the inter-relations of the criteria, conditioned the implementation of AHP method, as a method frequently used in research. During the construction of the model, the experts showed certainin accuracy when comparing pairs which is the requirement of the AHP method. With that regard the fuzzyfication of the method was performed. Similar output occurred with the MABAC method, which is emphasized as one of the methods which yields highly significant results. However, the course of examination showed that the experts are often hesitant when assigning the values to those criteria where there is no exact data. Hence, the degree of confidence was introduced in the ranking process, which was later mathematically processed.

When defining the method which should be used, the main criteria were the method stability and the ease of confirming the results. The stages and steps of the model are defined in Figure 1. When defining the method which should be used, the main criteria were the method stability and the ease of confirming the results. 


\begin{tabular}{|c|c|}
\hline 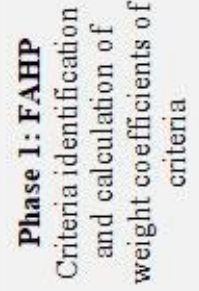 & $\begin{array}{l}\text { Step 1: Defining comparison matrices / comparison of criteria and } \\
\text { thedegree of certainty of experts in given claims/comparisons } \\
\text { Step 2: Calculation of the fuzzified matrices of the criteria comparison } \\
\text { Step 3: Calculation of weight fuzzy coefficients of criteria for } \\
\text { eachexpert separately } \\
\text { Step 4: Calculation of aggregated fuzzy weight coefficients of criteria } \\
\text { Step 5: Calculation of final (non-fuzzy) weight coefficients of criteria }\end{array}$ \\
\hline 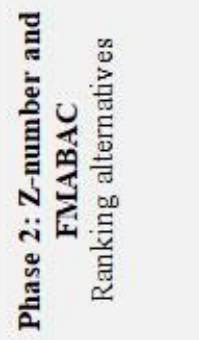 & $\begin{array}{l}\text { Step 1: Forming initial decision making matrix } \\
\text { Step 2: Reduction of initial decision making matrix values to standard } \\
\text { fuzzy numbers using Z-number } \\
\text { Step 3: Normalization of initial decision making matrix elements } \\
\text { Step 4: Calculation of weighted matrix (V) elements } \\
\text { Step 5: Determination of border approximate area matrix (G) } \\
\text { Step 6: Calculation of the distance between altematives and border } \\
\text { approximate areas } \\
\text { Step 7: Ranking alternatives }\end{array}$ \\
\hline
\end{tabular}

Figure 1

The stages and steps of the model

The used methods are described in the next part of the paper.

\subsection{Fuzzy AHP}

An Analytical Hierarchical Process (AHP) is a method often used in multi-criteria decision-making. This method was developed by Thomas Saaty. It is based on the explanation of a complex problem in the hierarchy, with the aim at the top, criteria, sub-criteria, and alternatives at the levels and subjections of the hierarchy [21]. Apart from the hierarchical structuring of the problem, AHP differs methodologically from other multiple-criteria methods, due to its comparisons of elements in pair on the given level of hierarchy with the elements on the higher level of hierarchy. For each of the elements at the higher level $n(n-1) / 2$ a comparison of semantic or numerical type, as defined with Saaty scale is needed,

Table 2. Saaty's scale is used to determine the weight coefficients of the criteria, as well as to rank the alternatives. 
Table 2

Saaty's scale for comparison in pairs

\begin{tabular}{ccc}
\hline Standard Values & Definition & Inverse values \\
\hline 1 & The same importance & 1 \\
3 & Week dominance & $1 / 3$ \\
5 & Strong dominance & $1 / 5$ \\
7 & Very strong dominance & $1 / 7$ \\
9 & Absolute dominance & $1 / 9$ \\
$2,4,6,8$ & Intervalues & $1 / 2,1 / 4,1 / 6,1 / 8$ \\
\hline
\end{tabular}

The comparison of elements on the given level of hierarchy yields the matrix of comparisons A:

$$
A=\left[\begin{array}{cccc}
a_{11} & a_{12} & \ldots & a_{1 n} \\
a_{21} & a_{22} & \ldots & a_{2 n} \\
\cdot & \cdot & \ldots & \cdot \\
\cdot & \cdot & \ldots & \cdot \\
a_{n 1} & a_{n 1} & \ldots & a_{n n}
\end{array}\right]
$$

The calculation of the weight coefficients, or in other words the ranking of alternatives, is related to different prioritizing approaches. Respectively, the most common approaches are the Eigenvector method (EV), Logarithmic Least Squares method (LLS), and Additive Normalization method (AN). In that regard, this research used the Additive Normalization method (AN).

The calculation of the priority vector $w$ is gained through 3 steps:

Step 1: each element from the given matrix column $A$ is divided with the sum of elements of that column;

Step 2: all elements in each column are gathered

Step 3: each of the given sums is divided with the range of matrix $n$

This procedure is described with visuals (2) and (3):

$$
\begin{gathered}
a_{i j}^{\prime}=\frac{a_{i j}}{\sum_{i=1}^{n} a_{i j}}, i, j=1,2, \ldots, n \\
w_{i}=\frac{\sum_{i=1}^{n} w_{i j}}{n}, \quad i=1,2, \ldots, n
\end{gathered}
$$

Very often Saaty's scale is being modified with the application of fuzzy sets. 
The basic items of the fuzzy logic were given by Lotfi Zadeh [22], [23], [24]. The basics that L Zadeh gave were sufficient to continue to develop fuzzy logic and to be increasingly applied in practice. In this paper, we use the triangular fuzzy numbers $T=\left(t_{1}, t_{2}, t_{3}\right)$, Figure 2, where $t_{1}$ represents the left, and $t_{3}$ the right distribution of the confidence interval of the fuzzy number $T$ and $t_{2}$, where the function of fuzzy number membership has a maximum value, one.

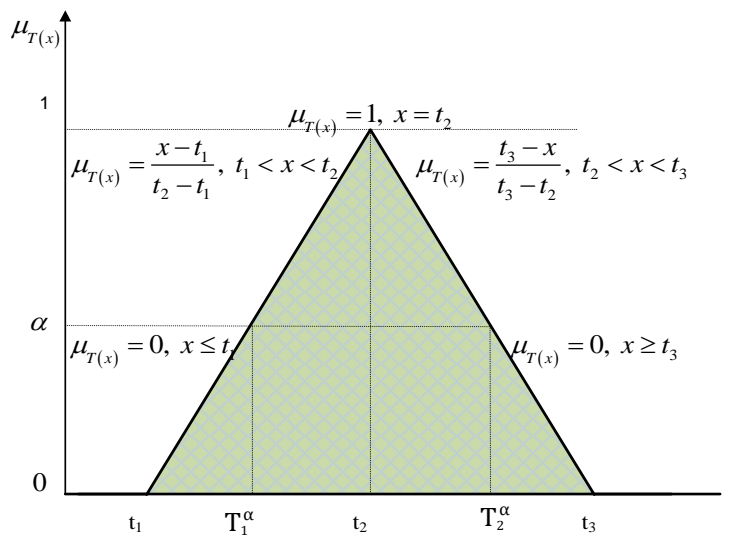

Figure 2

Triangular fuzzy number $\mathrm{T}[25]$

At the end of the application, the fuzzy number is converted to a real number. A number of methods are used for this procedure [26]. Some of the known defazification expressions are [27] [28]:

$\mathrm{A}=\left(\left(\mathrm{t}_{3}-\mathrm{t}_{1}\right)+\left(\mathrm{t}_{2}-\mathrm{t}_{1}\right)\right) / 3+\mathrm{t}_{1}$

$A=\left[\lambda t_{3}+t_{2}+(1-\lambda) t_{1}\right] / 2$

where $\lambda$ represents an index of optimism, which can be described as a belief/decision maker's relationship to decision-making risk [29]. The most common optimism index is $0,0.5$ or 1 , which corresponds to the pessimistic, average or optimistic view of the decision maker [29].

There are different approaches to fuzzification of Saaty's scale. In principle, they can be divided into two groups: sharp (hard) and soft fuzzification [30]. Under the "sharp" fuzzification, it is assumed that for a fuzzy number $T=\left(t_{1}, t_{2}, t_{3}\right)$ confidence interval is predetermined, i.e., it is defined in advance that the value of the fuzzy number will not be greater than $t_{3}$ nor less than $t_{1}$ [30]. In soft fuzzification, the confidence interval is not predetermined, but it is defined during the decisionmaking process, based on additional parameters.

A common occurrence is the definition of a scale with a smaller number of comparisons than Saaty's Six-step scale [31] [32] [33], while a five-step scale is used in Mandic et al, [34], Junior et al. [35] and Ruiz-Padillo et al. [36]. Most of 
these scales use the model of the fuzzy number $T=\left(t_{1}, t_{2}, t_{3}\right)=(x-1, x, x+1)$, where $x$ represents the standard value of Saaty's scale. Some authors modifies the Saaty scale use the model of the fuzzy number $T=(x-\delta, x, x+\delta)$, where $\delta$ is taken from the interval $0.5 \leq \delta \leq 2$ [37] [38] [39] [46]. In part of works [40] [41] instead of classical intervals, interval fuzzy numbers are used.

In some works, in addition to triangles, other forms of functions, trapezoidal, gauge curves and the like are used. Unlike the previous one, there are different "softer" approaches in the Saaty scale fuzzification, where the confidence interval of the fuzzy number is defined after the completed pairing. Such an approach is shown in Kahraman et al. [42] and Pamucar et al. [43]. The fuzzification shown in these works takes into account the degree of uncertainty $(\beta)$. Based on this, the new fuzzification, also used in this paper, is shown in Bozanic et al. [44], Pamucar et al. [45], Bozanic et al. [46] and Bojanic et al. [47]. The starting elements of this fuzzification are: 1) the introduction of fuzzy numbers instead of the classical numbers of the Saaty scale, 2) the introduction of the degree of conviction of decision makers/analysts/experts (DM/A/E) in the statements they give when compared in pairs $-\gamma$. The degree of conviction $\gamma$ is defined at the level of each pairing, Table 3 .

Table 3

Fuzzification of Saaty's scale using the degree of confidence

\begin{tabular}{|l|c|c|c|}
\hline Definition & $\begin{array}{l}\text { Standard } \\
\text { values }\end{array}$ & Fuzzy number & $\begin{array}{l}\text { Fuzzy number inverse } \\
\text { values }\end{array}$ \\
\hline The same importance & 1 & $(1,1,1)$ & $(1,1,1)$ \\
\hline Weak dominance & 3 & $\left(3 \gamma_{j i}, 3,\left(2-\gamma_{j i}\right) 3\right)$ & $\left(1 / 3 \gamma_{j i}, 1 / 3,1 /\left(2-\gamma_{j i}\right) 3\right)$ \\
\hline Strong dominance & 5 & $\left(5 \gamma_{j i}, 5,\left(2-\gamma_{j i}\right) 5\right)$ & $\left(1 / 5 \gamma_{j i}, 1 / 5,1 /\left(2-\gamma_{j i}\right) 5\right)$ \\
\hline Very strong dominance & 7 & $\left(7 \gamma_{j i}, 7,\left(2-\gamma_{j i}\right) 7\right)$ & $\left(1 / 7 \gamma_{j i}, 1 / 7,1 /\left(2-\gamma_{j i}\right) 7\right)$ \\
\hline Absolute dominance & 9 & $\left(9 \gamma_{j i}, 9,\left(2-\gamma_{j i}\right) 9\right)$ & $\left(1 / 9 \gamma_{j i}, 1 / 9,1 /\left(2-\gamma_{j i}\right) 9\right)$ \\
\hline In between values & $2,4,6,8$ & $\begin{array}{c}\left(x \gamma_{j i}, x,\left(2-\gamma_{j i}\right) x\right) \\
x=2,4,6,8\end{array}$ & $\begin{array}{c}\left(1 / x \gamma_{j i}, 1 / x, 1 /\left(2-\gamma_{j i}\right) x\right) \\
x=2,4,6,8\end{array}$ \\
\hline
\end{tabular}

Left and right distributions differ from one comparison to another when different degrees of confidence are introduced. They are changed according to the expression:

$\mathrm{T}=\left(\mathrm{t}_{1}, \mathrm{t}_{2}, \mathrm{t}_{3}\right)=\left\{\begin{array}{lrr}\mathrm{t}_{1}=\gamma \mathrm{t}_{2}, & \mathrm{t}_{1} \leq \mathrm{t}_{2}, & \mathrm{t}_{1}, \mathrm{t}_{2} \in[1 / 9,9] \\ \mathrm{t}_{2}=\mathrm{t}_{2}, & & \mathrm{t}_{2} \in[1 / 9,9] \\ \mathrm{t}_{3}=(2-\gamma) \mathrm{t}_{2}, & \mathrm{t}_{3} \leq \mathrm{t}_{2}, & \mathrm{t}_{2}, \mathrm{t}_{3} \in[1 / 9,9]\end{array}\right\}$

where the value $t_{2}$ represents the value of the linguistic expression from the classical Saaty scale, which in the fuzzy number has the maximum affiliation $t_{2}=1$.

This approach to fuzzification also requires an altered initial matrix of decisionmaking, that is, a matching matrix in pairs (and in cases where the weighting 
coefficients of the criteria and the ranking of the alternatives are defined). The modified matrix would have a new element - the degree of DM / A / E conviction that they would define in addition to the performed comparison:

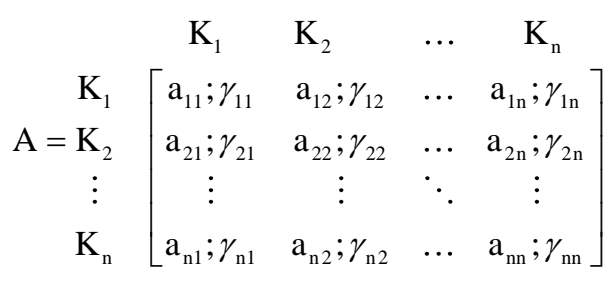

where $\gamma_{\mathrm{ji}}=\gamma_{\mathrm{ij}}$. Coming to the final results implies the further application of the standard steps of the AHP method.

\subsection{Z Number}

The concept of Z-number was proposed by Zadeh [48]. Kang et al. [49] [50] elaborate in detail the application of Z-number in an uncertain environment. Krohling et al. [51] show the application of Z-number with phasified methods TOPSIS and TODIM. Sahrom and Dom [52] elaborate a hybrid model using the AHP-Z-number-DEA method, while Azadeh and Kokabi [53] use the DEA method with Z-number. Azadeh et al. [54] use Z-number with the AHP method. Yaakob and Gegov [55] Z-number uses the TOPSIS method. Salari et al. [56] elaborate a novel earned value management model using Z-number. Z-number represents an ordered pair of fuzzy numbers that appear as $Z=(\tilde{A}, \tilde{B})$ [48]. The first component, fuzzy number $\tilde{A}$, represents the fuzzy limit of a particular variable $X$, while the second component fuzzy number $\tilde{\mathrm{B}}$ represents, the reliability of the first component ( $\tilde{\mathrm{A}}$ ). The appearance of the Z-number with triangular fuzzy numbers is shown in Figure 4 [48].

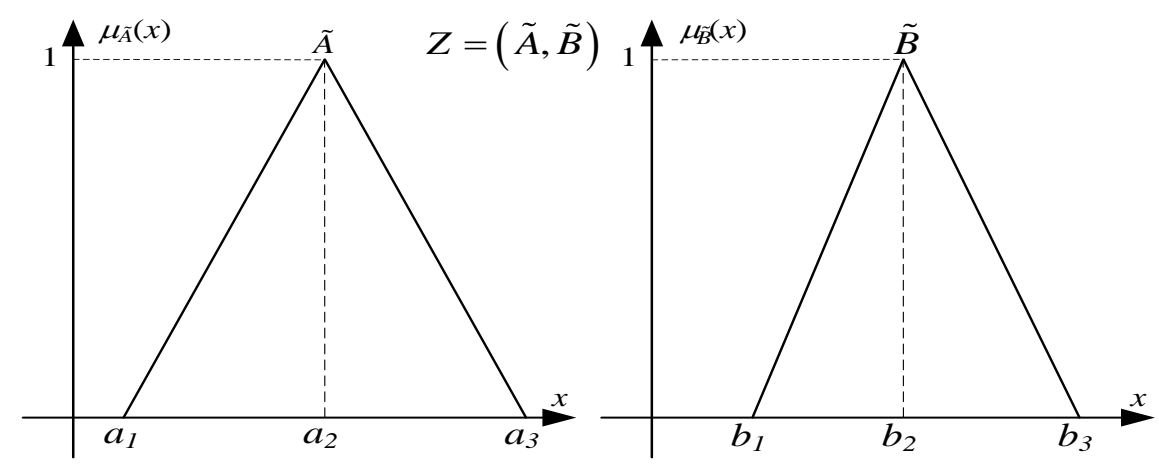

Figure 4

A-Simple Z-number [49] 
The general record of triangular Z-numbers can be displayed as $\tilde{\mathrm{Z}}=\left\{\left(\mathrm{a}_{1}, \mathrm{a}_{2}, \mathrm{a}_{3} ; \mathrm{w}_{\tilde{\mathrm{A}}}\right),\left(\mathrm{b}_{1}, \mathrm{~b}_{2}, \mathrm{~b}_{3} ; \mathrm{w}_{\tilde{\mathrm{B}}}\right)\right\}$

where the values $\mathrm{w}_{\tilde{\mathrm{A}}} \mathrm{i} \mathrm{W}_{\tilde{\mathrm{B}}}$ represent weight factors of fuzzy numbers $\tilde{\mathrm{A}}$ referring to $\tilde{\mathrm{B}}$, which for the initial Z-number the majority of authors defines as $\mathrm{w}_{\tilde{\mathrm{A}}}=\mathrm{w}_{\tilde{\mathrm{B}}}=1, \mathrm{w}_{\tilde{\mathrm{A}}}, \mathrm{w}_{\tilde{\mathrm{B}}} \in[0,1] \quad\left(\mathrm{w}_{\tilde{\mathrm{A}}}\right.$ is the height of the generalized fuzzy number and $0 \leq \mathrm{w}_{\tilde{\mathrm{A}}} \leq 1$ ) [57]. Defining values $\mathrm{w}_{\tilde{\mathrm{B}}}<1$ would introduce a greater degree of uncertainty in defining Z-number When $\mathrm{w}_{\tilde{\mathrm{A}}}=\mathrm{w}_{\tilde{\mathrm{B}}}=1$, then $\mathrm{A}$ and $\mathrm{B}$ is a normal fuzzy number; otherwise it is said to be a non-normal fuzzy number [58]. The transformation of the Z-number into the classical fuzzy number, with the presented evidence, is shown in Kang et al. [50]. This transformation consists of three steps:

Convert the second part ( $\tilde{B})$ into a crisp number using the centered method [50]:

$\alpha=\frac{\int \mathrm{x} \mu_{\tilde{\mathrm{B}}}(\mathrm{x}) \mathrm{dx}}{\int \mu_{\tilde{\mathrm{B}}}(\mathrm{x}) \mathrm{dx}}$

where $\int$ denotes an algebraic integration.

For triangular fuzzy numbers, the centroid is calculated by [59]:

$\alpha=\frac{\mathrm{a}_{1}+\mathrm{a}_{2}+\mathrm{a}_{3}}{3}$

Add the weight of the second part $(\tilde{B})$ to the first part $(\tilde{A})$. The weighted Znumber can be denoted as [50]

$$
\tilde{\mathrm{Z}}^{\alpha}=\left\{\left\langle\mathrm{x}, \mu_{\tilde{\mathrm{A}}^{\alpha}}(\mathrm{x})\right\rangle \mid \mu_{\tilde{\mathrm{A}}^{\alpha}}(\mathrm{x})=\alpha \mu_{\tilde{\mathrm{A}}}(\mathrm{x})\right\}
$$

which can be denoted by the Fig. 5 a.

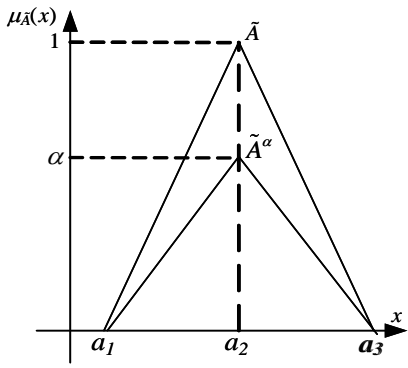

a)

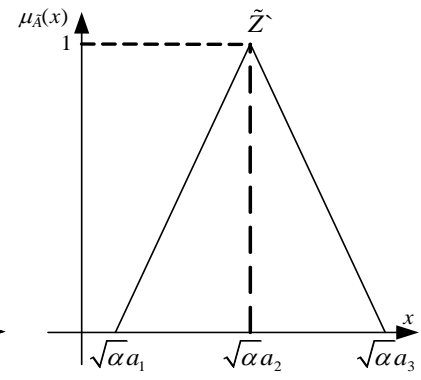

b)

Figure 5

Z-number after multiplying the reliability (a) and the regular fuzzy number transformed from Znumber (b) 
This can be written as [54]: $\tilde{\mathrm{Z}}^{\alpha}=\left(\mathrm{a}_{1}, \mathrm{a}_{2}, \mathrm{a}_{3} ; \alpha\right)$

Convert the weighted Z-number into a regular fuzzy number. The regular fuzzy set can be denoted as [50]

$$
\begin{aligned}
& \tilde{\mathrm{Z}}=\left\{\left\langle\mathrm{x}, \mu_{\overline{\mathrm{Z}}}(\mathrm{x})\right\rangle \mid \mu_{\tilde{\mathrm{Z}}}(\mathrm{x})=\mu_{\tilde{\mathrm{A}}}\left(\frac{\mathrm{x}}{\sqrt{\alpha}}\right)\right\} \\
& \tilde{\mathrm{Z}}=\sqrt{\alpha} * \tilde{\mathrm{A}}=\left(\sqrt{\alpha} * \mathrm{a}_{1}, \sqrt{\alpha} * \mathrm{a}_{2}, \sqrt{\alpha} * \mathrm{a}_{3}\right)
\end{aligned}
$$

and it can be present as Fig. $5 b$ [50].

\subsection{Fuzzy MABAC Method}

The MABAC method is developed by Pamucar \& Cirovic [60]. The basic setting of the MABAC method consists in defining the distance of the criteria function of every observed alternative from the border approximate area. The method was later used in several papers [44], [46], [47] [61]. The Fuzzy MABAC method consists of 6 steps [46]:

Step 1. Forming of the initial decision matrix ( $\tilde{\mathrm{X}}$ ). Matrix is formed with a grade of alternatives based on criteria $A_{i}=\left(\tilde{x}_{i 1}, \tilde{x}_{i 2} \ldots, \tilde{x}_{i n}\right)$, where $\tilde{x}_{i j}$ represents the value of $\mathrm{i}$-th alternative $(i=1,2, \ldots \mathrm{m})$, based on $\mathrm{j}$-th criteria $(j=1,2, \ldots, \mathrm{n})$.

$$
\tilde{X}=\begin{gathered}
K_{1} \\
A_{1} \\
A_{2} \\
\ldots \\
A_{m}
\end{gathered}\left[\begin{array}{cccc}
\tilde{x}_{11} & \tilde{x}_{12} & \ldots & K_{n} \\
\tilde{x}_{11} & \tilde{x}_{22} & & \tilde{x}_{2 n} \\
\ldots & \ldots & \ldots & \ldots \\
\tilde{x}_{1 m} & \tilde{x}_{2 m} & \ldots & \tilde{x}_{m n}
\end{array}\right]
$$

Step 2. Normalization of the initial matrix elements $(\tilde{X})$.

The calculation of the elements of normalized matrix $(\tilde{N})$ depends on the type of criteria. For beneficial criteria this calculation is executed according to the expression:

$$
\tilde{t}_{i j}=\frac{x_{i j}-x_{i}^{-}}{x_{i}^{+}-x_{i}^{-}}
$$

For detriment criteria the calculation is executed according to the expression:

$$
\tilde{t}_{i j}=\frac{x_{i j}-x_{i}^{+}}{x_{i}^{-}-x_{i}^{+}}
$$


Values $x_{i j}, x_{i}^{+}, x_{i}^{-}$represent elements of the initial matrix of decision-making $(\tilde{X})$. The values $x_{i}^{+}, x_{i}^{-}$are defined as explanied bellow

$-x_{i}^{+}=\max \left(x_{1 r}, x_{2 r}, \ldots, x_{m r}\right)$ - represent maximal values of the right distribution of fuzzy numbers of the observed criteria alternatives

$-x_{i}^{-}=\min \left(x_{1 l}, x_{2 l}, \ldots, x_{m l}\right) \quad$ - represent minimal values of the left distribution of fuzzy numbers of the observed criteria alternatives.

Consequently, the normalized matrix $(\tilde{N})$ is calculated

$$
\tilde{N}=\begin{gathered}
K_{1} \\
A_{1} \\
A_{2} \\
\ldots \\
A_{m}
\end{gathered}\left[\begin{array}{cccc}
\tilde{t}_{11} & \tilde{t}_{12} & \ldots & \tilde{t}_{1 n} \\
\tilde{t}_{11} & \tilde{t}_{22} & & \tilde{t}_{2 n} \\
\ldots & \ldots & \ldots & \ldots \\
\tilde{t}_{1 m} & \tilde{t}_{2 m} & \ldots & \tilde{t}_{m n}
\end{array}\right]
$$

Step 3. Calculation of the weighted matrix ( $\tilde{\mathrm{V}})$ elements.

Elements of this matrix are calculated based on the following expression:

$\tilde{v}_{i j}=w_{i}\left[\tilde{t}_{i j}+w_{i}\right.$

In the previous expression $\tilde{t}_{i j}$ represents elements of the normalized matrix $(\tilde{N})$, whereas $w_{i}$ epresents weight coefficients of the criteria. Weighted matrix $(\tilde{\mathrm{V}})$ is visualized in the following way

$$
\tilde{V}=\left[\begin{array}{cccc}
\tilde{v}_{11} & \tilde{v}_{12} & \ldots & \tilde{v}_{1 n} \\
\tilde{v}_{21} & \tilde{v}_{22} & \ldots & \tilde{v}_{2 n} \\
\ldots & \ldots & \ldots & \ldots \\
\tilde{v}_{m 1} & \tilde{v}_{m 2} & \ldots & \tilde{v}_{m n}
\end{array}\right]
$$

Step 4. Determination of the approximate border area matrix $(\tilde{\mathrm{G}})$. The bordering approximate area for each criteria is determined based on the expression:

$\tilde{g}_{i}=\left(\prod_{j=1}^{m} \tilde{v}_{i j}\right)^{1 / m}$

The matrix of approximate area $(\tilde{G})$ has a format $\mathrm{n} \times 1$, where $\mathrm{n}$ presents overall sum of criteria number and is represented in the following way

$$
\left.\tilde{G}=\begin{array}{rrrr}
K_{1} & K_{2} & \ldots & K_{n} \\
{\left[\tilde{g}_{1}\right.} & \tilde{g}_{2} & \ldots & \tilde{g}_{n}
\end{array}\right]
$$


Step 5. Calculation of the matrix elements of alternatives distance from the border approximate area ( $\tilde{Q})$. The distance of alternatives from the border approximate area $\left(\tilde{q}_{i j}\right)$ is defined with the expression:

$\tilde{Q}=\tilde{V}-\tilde{G}$

Afterwards the matrix is calculated $\tilde{Q}$

$$
\tilde{Q}=\left[\begin{array}{cccc}
\tilde{q}_{11} & \tilde{q}_{12} & \ldots & \tilde{q}_{1 n} \\
\tilde{q}_{21} & \tilde{q}_{22} & & \tilde{q}_{2 n} \\
\ldots & \ldots & \ldots & \ldots \\
\tilde{q}_{m 1} & \tilde{q}_{m 2} & \ldots & \tilde{q}_{m n}
\end{array}\right]
$$

Step 6. Ranking of alternatives. The value estimation of criteria functions of alternatives is gained from the sum of the distance of alternatives from the border approximate areas $\left(\tilde{q}_{i}\right)$. The ultimate values of criteria functions of alternatives are gained from the sum of elements of the matrix $\tilde{Q}$ in rows:

$\tilde{S}_{i}=\sum_{j=1}^{n} \tilde{q}_{i j}, j=1,2, \ldots, n, i=1,2, \ldots, m$

Defuzzification of the extracted values $\tilde{S}_{i}$ yields the ultimate rang alternatives.

\section{Application of the Model to the Ranking of Social Media Platforms}

Based on previous experience and with regard to the fact that the surveyed experts are from the field of public relations, and available data from various sources, for example data from institute for statistics, relevant analytical websites, academic and expert literature which covers the field of social media for commercial purposes. The first experts summary of all data classified according to the criteria from available resources is presented in Table 4.

Table 4

Summary of all data classified according to the criteria

\begin{tabular}{|c|c|c|c|c|c|c|}
\hline Alternative & Functionality & $\begin{array}{c}\text { Target } \\
\text { audience }\end{array}$ & $\begin{array}{c}\text { Content } \\
\text { richness }\end{array}$ & Purpose & Precence & Engagement \\
\hline Blogs & 5 & 100 & 4 & 5 & 0,1 & 3 \\
\hline Facebook & 7 & 56 & 5 & 4 & 1721 & 5 \\
\hline Youtube & 4 & 63 & 3 & 4 & 1325 & 3 \\
\hline
\end{tabular}




\begin{tabular}{|c|c|c|c|c|c|c|}
\hline Twitter & 5 & 33 & 4 & 4 & 342 & 4 \\
\hline LinkedIn & 3 & 12 & 4 & 4 & 380 & 2 \\
\hline Pinterest & 5 & 8 & 3 & 3 & 73 & 4 \\
\hline Flicker & 4 & 3 & 3 & 3 & 120 & 3 \\
\hline Instagram & 7 & 63 & 3 & 3 & 500 & 4 \\
\hline Wikipedia & 1 & 23 & 1 & 2 & 1500 & 1 \\
\hline Vimeo & 4 & 3 & 3 & 4 & 40 & 3 \\
\hline
\end{tabular}

The experts performed a comparison of the significance of the selected criteria, using the Saaty scale, and defined the degree of conviction in the comparisons they gave. This defined the initial decision matrices for each expert. Defining the degree of conviction was done using the fuzzy linguistic scale shown in Figure 6.

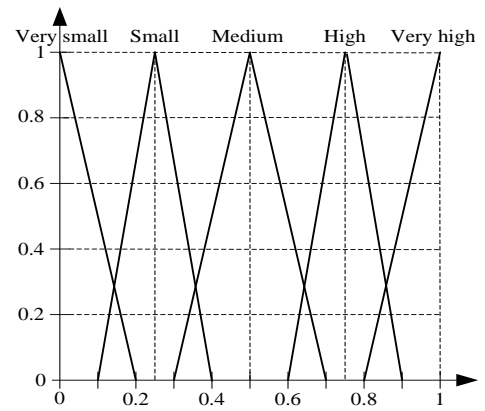

Figure 6

Fuzzy linguistic descriptors for evaluating the degree of conviction of experts

Table 4 shows the comparison of the criteria of the first expert, with degrees of confidence in data comparisons (degrees of conviction are shown in brackets). The implementation of the fuzzy AHP method will only be performed on the initial decision-making matrix of an expert.

Table 5

The initial matrix of deciding the expert 1 for defining the weight coefficients of the criterion

\begin{tabular}{|c|c|c|c|c|c|c|}
\hline Criteria & $\mathrm{C}_{1}$ & $\mathrm{C}_{2}$ & $\mathrm{C}_{3}$ & $\mathrm{C}_{4}$ & $\mathrm{C}_{5}$ & $\mathrm{C}_{6}$ \\
\hline $\mathrm{C}_{1}$ & 1 & $3(\mathrm{VH})$ & $5(\mathrm{H})$ & $4(\mathrm{H})$ & $2(\mathrm{H})$ & $4(\mathrm{VH})$ \\
\hline $\mathrm{C}_{2}$ & $1 / 3(\mathrm{VH})$ & 1 & $3(\mathrm{H})$ & $3(\mathrm{VH})$ & $1 / 3(\mathrm{VH})$ & $2(\mathrm{~S})$ \\
\hline $\mathrm{C}_{3}$ & $1 / 5(\mathrm{H})$ & $1 / 3(\mathrm{H})$ & 1 & $1 / 2(\mathrm{VS})$ & $1 / 6(\mathrm{VH})$ & $1 / 3(\mathrm{M})$ \\
\hline $\mathrm{C}_{4}$ & $1 / 4(\mathrm{H})$ & $1 / 3(\mathrm{VH})$ & $2(\mathrm{VS})$ & 1 & $1 / 5(\mathrm{M})$ & $1 / 2(\mathrm{VH})$ \\
\hline $\mathrm{C}_{5}$ & $1 / 2(\mathrm{H})$ & $3(\mathrm{VH})$ & $6(\mathrm{VH})$ & $5(\mathrm{M})$ & 1 & $6(\mathrm{VH})$ \\
\hline $\mathrm{C}_{6}$ & $1 / 4(\mathrm{VH})$ & $1 / 2(\mathrm{~S})$ & $3(\mathrm{M})$ & $2(\mathrm{VH})$ & $1 / 6(\mathrm{VH})$ & 1 \\
\hline
\end{tabular}

$$
\frac{\tilde{\mathrm{C}}_{1}}{\tilde{\mathrm{C}}_{2}}=(3 * 0.933,3,(2-0.933) * 3)=(2.8,3,3.2)
$$

In the next step, the initial decision matrix was initialized using the terms given in Table 5. The Fuzzy comparison C1 / C2 was obtained as follows: 
Where value $\gamma_{\mathrm{ji}}=0.933$ represents the degree of conviction obtained using the expression (5), the displayed linguistic descriptors in Figure 6 and based on the expert's test that the degree of conviction in his claim is "very high". The given value was obtained as follows:

$$
\gamma_{\mathrm{ji}}=((1-0.75)+(1-0.75)) / 3+0.75=0.933
$$

All values of the fuzzified initial decision matrix are shown in Table 6. Next, the standard steps of the AHP method are applied. First, column addition is done. The results in the first column were done as follows:

$$
\begin{aligned}
& \sum_{j=1}^{n} \tilde{C}_{j}^{1}=(1+0.31+0.16,+0.2+0.4+0.23,1+0.33+0.2+0.25+0.5+0.25, \\
& 1+0.36+0.27+0.33+0.67+0.27)=(2.3,2.53,2.9), n=1,2 \ldots 6 ;
\end{aligned}
$$

\begin{tabular}{|c|c|c|c|c|c|c|}
\hline Criteria & $\mathrm{C}_{1}$ & $\mathrm{C}_{2}$ & $\mathrm{C}_{3}$ & $\mathrm{C}_{4}$ & $\mathrm{C}_{5}$ & $\mathrm{C}_{6}$ \\
\hline $\mathrm{C}_{1}$ & $(1,1,1)$ & $\begin{array}{c}(2.8,3, \\
3.2)\end{array}$ & $\begin{array}{c}(3.75,5, \\
6.25)\end{array}$ & $(3,4,5)$ & $\begin{array}{c}(1.5,2, \\
2.5)\end{array}$ & $\begin{array}{c}(3.73,4, \\
4.27)\end{array}$ \\
\hline $\mathrm{C}_{2}$ & $\begin{array}{c}(0.31,0.33 \\
0.36)\end{array}$ & $(1,1,1)$ & $\begin{array}{c}(2.25,3, \\
3.75)\end{array}$ & $\begin{array}{c}(2.8,3, \\
3.2)\end{array}$ & $\begin{array}{c}(0.31,0.33 \\
0.36)\end{array}$ & $\begin{array}{l}(1,2, \\
3.5)\end{array}$ \\
\hline $\mathrm{C}_{3}$ & $\begin{array}{c}(0.16,0.2 \\
0.27)\end{array}$ & $\begin{array}{c}(0.27,0.33 \\
0.44)\end{array}$ & $(1,1,1)$ & $(0.26,0.5,1)$ & $\begin{array}{c}(0.16,0.17 \\
0.18)\end{array}$ & $\begin{array}{c}(0.22,0.33 \\
0.67)\end{array}$ \\
\hline $\mathrm{C}_{4}$ & $\begin{array}{c}(0.2,0.25 \\
0.33)\end{array}$ & $\begin{array}{c}(0.31,0.33 \\
0.36)\end{array}$ & $(1,2,3.87)$ & $(1,1,1)$ & $\begin{array}{c}(0.13,0.2 \\
0.4)\end{array}$ & $\begin{array}{c}(0.47,0.5 \\
0.54)\end{array}$ \\
\hline $\mathrm{C}_{5}$ & $\begin{array}{c}(0.4,0.5 \\
0.67)\end{array}$ & $\begin{array}{c}(2.8,3, \\
3.2)\end{array}$ & $\begin{array}{c}(5.6,6 \\
6.4)\end{array}$ & $\begin{array}{c}(2.5,5) \\
7.5)\end{array}$ & $(1,1,1)$ & $\begin{array}{c}(5.6,6, \\
6.4)\end{array}$ \\
\hline $\mathrm{C}_{6}$ & $\begin{array}{c}(0.23,0.25 \\
0.27)\end{array}$ & $\begin{array}{c}(0.29,0.5 \\
1)\end{array}$ & $(1.5,3,4.5)$ & $(1.87,2,2.13)$ & $\begin{array}{c}(0.16,0.17 \\
0.18)\end{array}$ & $(1,1,1)$ \\
\hline$\sum_{j=1}^{n} C j$ & $\begin{array}{c}(2.3,2.53 \\
2.9)\end{array}$ & $\begin{array}{c}(7.47,8.16,9 \\
20)\end{array}$ & $\begin{array}{c}(15.1,20 \\
25.77)\end{array}$ & $\begin{array}{c}(11.43,15.5, \\
19.83)\end{array}$ & $\begin{array}{c}(3.26,3.87 \\
4.62)\end{array}$ & $\begin{array}{c}(13.02,13.83, \\
16.38)\end{array}$ \\
\hline
\end{tabular}

Table 6

Fuzzified initial decision matrix for expert 1

Next, the fuzzy numbers were divided by a collection of columns, using standard fuzzy arithmetic:

$$
\left(\frac{\tilde{\mathrm{C}}_{1}}{\tilde{\mathrm{C}}_{2}}\right) / \sum_{\mathrm{j}=1}^{\mathrm{n}} \tilde{\mathrm{C}}_{\mathrm{j}}=\left(\frac{1}{2.9}, \frac{1}{2.53}, \frac{1}{2.3}\right)=(0.35,0.4,0.43)
$$

Then column addition is done:

$$
\begin{aligned}
& \sum_{\mathrm{i}=1}^{\mathrm{n}} \tilde{\mathrm{C}}_{\mathrm{i}}^{1}=(0.35+0.3+0.15+0.15+0.33+0.23,0.39+0.37+0.25+0.26+0.52+0.29, \\
& 0.43+0.43+0.41+0.44+0.77+0.35)=(1.5,2.08,2.84), \mathrm{n}=1,2 \ldots 6,
\end{aligned}
$$

The other values are shown in Table 7. 
Table 7

Values of AHP methods

\begin{tabular}{|c|c|c|c|c|c|c|c|}
\hline Criteria & $\mathrm{C}_{1}$ & $\mathrm{C}_{2}$ & $\mathrm{C}_{3}$ & $\mathrm{C}_{4}$ & $\mathrm{C}_{5}$ & $\mathrm{C}_{6}$ & \\
\hline $\mathrm{C}_{1}$ & $\begin{array}{c}(0.35,0.39 \\
0.43)\end{array}$ & $\begin{array}{c}(0.30,0.37, \\
0.43)\end{array}$ & $\begin{array}{c}(0.15,0.25 \\
0.41)\end{array}$ & $\begin{array}{c}(0.15,0.26 \\
0.44)\end{array}$ & $\begin{array}{c}(0.33,0.52, \\
0.77)\end{array}$ & $\begin{array}{c}(0.23,0.29 \\
0.35)\end{array}$ & $\begin{array}{c}(1.50,2.08 \\
2.84)\end{array}$ \\
\hline $\mathrm{C}_{2}$ & $\begin{array}{c}(0.11,0.13, \\
0.15)\end{array}$ & $\begin{array}{c}(0.11,0.12, \\
0.13)\end{array}$ & $\begin{array}{c}(0.09,0.15 \\
0.25)\end{array}$ & $\begin{array}{c}(0.14,0.19, \\
0.28)\end{array}$ & $\begin{array}{c}(0.07,0.09 \\
0.11)\end{array}$ & $\begin{array}{c}(0.06,0.14 \\
0.29)\end{array}$ & $\left(\begin{array}{c}0.57,0.83 \\
1.22)\end{array}\right.$ \\
\hline $\mathrm{C}_{3}$ & $\begin{array}{c}(0.06,0.08, \\
0.12)\end{array}$ & $\begin{array}{c}(0.03,0.04, \\
0.06)\end{array}$ & $\begin{array}{c}(0.04,0.05 \\
0.07)\end{array}$ & $\begin{array}{c}(0.01,0.03, \\
0.09)\end{array}$ & $\begin{array}{c}(0.03,0.04, \\
0.05)\end{array}$ & $\left(\begin{array}{c}(0.01,0.02 \\
0.06)\end{array}\right.$ & $\begin{array}{c}(0.18,0.27 \\
0.44)\end{array}$ \\
\hline $\mathrm{C}_{4}$ & $\begin{array}{c}(0.07,0.1 \\
0.14)\end{array}$ & $\begin{array}{c}(0.03,0.04, \\
0.05)\end{array}$ & $\begin{array}{c}(0.04,0.1, \\
0.26)\end{array}$ & $\begin{array}{c}(0.05,0.06, \\
0.09)\end{array}$ & $\begin{array}{c}(0.03,0.05, \\
0.12)\end{array}$ & $\begin{array}{c}(0.03,0.04 \\
0.04)\end{array}$ & $\begin{array}{c}(0.25,0.39 \\
0.7)\end{array}$ \\
\hline $\mathrm{C}_{5}$ & $\begin{array}{c}(0.14,0.2 \\
0.29)\end{array}$ & $\begin{array}{c}(0.30,0.37, \\
0.43)\end{array}$ & $\begin{array}{c}(0.22,0.3 \\
0.42)\end{array}$ & $\begin{array}{c}(0.13,0.32, \\
0.66)\end{array}$ & $\begin{array}{c}(0.22,0.26, \\
0.31)\end{array}$ & $\begin{array}{c}(0.34,0.43 \\
0.53)\end{array}$ & $\begin{array}{c}(1.34,1.88 \\
2.64)\end{array}$ \\
\hline $\mathrm{C}_{6}$ & $\begin{array}{c}(0.08,0.1 \\
0.12)\end{array}$ & $\begin{array}{c}(0.03,0.06, \\
0.13)\end{array}$ & $\begin{array}{c}(0.06,0.15, \\
0.3)\end{array}$ & $\begin{array}{c}(0.09,0.13, \\
0.19)\end{array}$ & $\begin{array}{c}(0.03,0.04, \\
0.05)\end{array}$ & $\begin{array}{c}(0.06,0.07 \\
0.08)\end{array}$ & $\begin{array}{c}(0.36,0.55 \\
0.87)\end{array}$ \\
\hline
\end{tabular}

The final values of the weight coefficients were obtained by dividing the sum of the rows with the number of criteria (n):

$\sum_{\mathrm{i}=1}^{\mathrm{n}} \tilde{\mathrm{C}}_{\mathrm{i}}^{1} / \mathrm{n}=\left(\frac{1.5}{6}, \frac{2.08}{6}, \frac{2.84}{6}\right)=(0.25,0.346,0.473)$

The steps shown are the standard steps of the AHP method, which resulted in the fuzzy weight coefficients of the criteria for the first expert $\left(\tilde{w}_{\text {ej }}, j=1, \ldots 6, e=1,2, \ldots 11\right)$, Table 8 .

Table 8

Fuzzy weight coefficients obtained using expert data 1

\begin{tabular}{|c|c|}
\hline Criterion & $\tilde{\mathrm{w}}_{\text {ej }}, \mathrm{e}=1$ \\
\hline $\mathrm{C}_{1}$ & $(0.25,0,346,0.473)$ \\
\hline $\mathrm{C}_{2}$ & $(0.096,0.138,0.203)$ \\
\hline $\mathrm{C}_{3}$ & $(0.031,0.045,0.073)$ \\
\hline $\mathrm{C}_{4}$ & $(0.042,0.065,0.017)$ \\
\hline $\mathrm{C}_{5}$ & $(0.224,0.313,0.44)$ \\
\hline $\mathrm{C}_{6}$ & $(0.06,0.092,0.145)$ \\
\hline
\end{tabular}

In order to compare the obtained results, the defuzzification of the obtained values was performed for the first expert and the normalization of value was done. The values of weight coefficients obtained from the comparison of the first expert are shown in Table 9. 
Table 9

Comparative overview of weight coefficients obtained by classical and fuzzy AHP method

\begin{tabular}{|c|c|c|c|c|c|c|}
\hline \multirow[b]{2}{*}{ :0ี } & \multirow[b]{2}{*}{$\begin{array}{l}\text { Classical } \\
\text { AHP } \\
\text { method }\end{array}$} & \multicolumn{5}{|c|}{ Fuzzy AHP } \\
\hline & & $\begin{array}{c}\text { Defuzzification } \\
\tilde{\mathrm{W}}_{1 \mathrm{j}} \text { applying } \\
\text { expression } 4\end{array}$ & $\begin{array}{c}\text { Defuzzification } \\
\tilde{\mathrm{w}}_{1 \mathrm{j}} \text { applying } \\
\text { expression 5, } \\
\lambda=0\end{array}$ & $\begin{array}{c}\text { Defuzzification } \\
\tilde{\mathrm{w}}_{1 \mathrm{j}} \text { applying } \\
\text { expression 5, } \\
\lambda=0.5\end{array}$ & $\begin{array}{c}\text { Defuzzification } \\
\tilde{\mathrm{w}}_{1 \mathrm{j}} \text { applying } \\
\text { expression } 5, \\
\lambda=1\end{array}$ & Rank \\
\hline $\mathrm{C}_{1}$ & 0.346 & 0.339 & 0.350 & 0.341 & 0.334 & 1 \\
\hline $\mathrm{C}_{2}$ & 0.138 & 0.139 & 0.138 & 0.138 & 0.140 & 3 \\
\hline $\mathrm{C}_{3}$ & 0.045 & 0.047 & 0.044 & 0.046 & 0.048 & 6 \\
\hline $\mathrm{C}_{4}$ & 0.065 & 0.071 & 0.063 & 0.070 & 0.074 & 5 \\
\hline $\mathrm{C}_{5}$ & 0.313 & 0.310 & 0.316 & 0.311 & 0.307 & 2 \\
\hline $\mathrm{C}_{6}$ & 0.092 & 0.094 & 0.089 & 0.094 & 0.097 & 4 \\
\hline
\end{tabular}

The differences observed between the application of classical AHP method and the fuzzy AHP methods are not large. Essential differences are noticed on the second and third decimals of weight coefficients, even though they represent minor differences. These differences also depend on the approach to fuzzification of the fuzzy weight coefficient of the criteria. The table provides two approaches or four budgets. As seen from the table, classical comparison in pairs is still dominant in the application of the method, while the degree of conviction is only an ancillary. These differences increase when multiple researchers use the analysis.

In further work, we calculated the weight coefficients for each expert. The obtained results were aggregated so one fuzzy number was obtained, which describes the weight coefficients, and which by using expression (5) is defuzzified. The final values of weight coefficients are given in Table 10.

Table 10

Final weight coefficients of the criterion

\begin{tabular}{|c|c|c|}
\hline Criterion & Final weight coefficient $(\mathrm{w})$ & Rank \\
\hline $\mathrm{C}_{1}$ & 0.351 & 1 \\
\hline $\mathrm{C}_{2}$ & 0.113 & 3 \\
\hline $\mathrm{C}_{3}$ & 0.063 & 6 \\
\hline $\mathrm{C}_{4}$ & 0.074 & 5 \\
\hline $\mathrm{C}_{5}$ & 0.318 & 2 \\
\hline $\mathrm{C}_{6}$ & 0.081 & 4 \\
\hline
\end{tabular}

After defining the weight coefficients, using the fuzzy MABAC method ranking of the alternative was performed. Ten alternatives are ranked. The values for the criteria $\mathrm{C} 1, \mathrm{C} 2$ and $\mathrm{C} 5$ are precisely defined, while the values for the criteria $\mathrm{C} 3$, 
C4 and C6 are defined with two fuzzy or Z numbers: $\tilde{A}$ - which represents the value of the fuzzy number and $\tilde{B}$ - which represents the degree of the conviction of the experts in the described values. The initial matrix of decision-making $(\tilde{X})$ is shown in Table 11 .

Table 11

The starting matrix of decision-making in ranking alternatives

\begin{tabular}{|c|c|c|c|c|c|c|c|c|c|c|}
\hline \multirow{2}{*}{ Alternative } & \multirow{2}{*}{$\begin{array}{c}\text { Alternative } \\
\text { index }\end{array}$} & \multirow{2}{*}{$\mathrm{C}_{1}$} & \multirow{2}{*}{$\mathrm{C}_{2}$} & \multicolumn{2}{|l|}{$\mathrm{C}_{3}$} & \multicolumn{2}{|l|}{$\mathrm{C}_{4}$} & \multirow{2}{*}{$\mathrm{C}_{5}$} & \multicolumn{2}{|l|}{$\mathrm{C}_{6}$} \\
\hline & & & & $\tilde{A}$ & $\tilde{\mathrm{B}}$ & $\tilde{A}$ & $\tilde{\mathrm{B}}$ & & $\tilde{\mathrm{A}}$ & $\tilde{\mathrm{B}}$ \\
\hline Blogs & $\mathrm{A}_{1}$ & 5 & 4 & $(45,50,55)$ & VM & $(4.5,5,5)$ & $\mathrm{M}$ & 0.1 & $(2.5,3,3.5)$ & M \\
\hline Facebook & & 7 & 5 & $(85,90,95)$ & M & $(3.5,4,4.5)$ & V & 1721 & $(4.5,5,5)$ & M \\
\hline Youtube & & 4 & 3 & $(90,95,100)$ & $\mathrm{S}$ & $(3.5,4,4.5)$ & VV & 1325 & $(2.5,3,3.5)$ & VV \\
\hline Twit & & 5 & 4 & $(28,33,38)$ & $S$ & $(3.5,4,4.5)$ & $S$ & 342 & $(3.5,4,4.5)$ & $\mathrm{S}$ \\
\hline LinkedIn & & 3 & 3 & $(29,34,40)$ & VM & $(3.5,4,4.5)$ & M & 380 & $(1.5,2,2.5)$ & $\mathrm{VM}$ \\
\hline Pinterest & & 5 & 3 & $(22,27,32)$ & VV & $(2.5,3,3.5)$ & VV & 73 & $(3.5,4,4.5)$ & V \\
\hline Flicker & & 4 & 3 & $(7,12,17)$ & V & $(2.5,3,3.5)$ & $\mathrm{S}$ & 120 & $(2.5,3,3.5)$ & $S$ \\
\hline Instagram & $\mathrm{A}_{8}$ & 7 & 3 & $(81,86,91)$ & $S$ & $(2.5,3,3.5)$ & $\mathrm{VM}$ & 500 & $(4.5,5,5)$ & $\mathrm{VM}$ \\
\hline Wikipedia & $A_{0}$ & 1 & 1 & $(51,56,61)$ & $\mathrm{VV}$ & $(1.5,2,2.5)$ & VM & 1500 & $(1,1,1)$ & $\mathrm{V}$ \\
\hline Vimeo & $\mathrm{A}_{10}$ & 4 & 3 & $(0,4,9)$ & $M$ & $(3.5,4,4.5)$ & $\mathrm{V}$ & 40 & $(2.5,3,3.5)$ & $\mathrm{VV}$ \\
\hline
\end{tabular}

In the next step, the phasing of linguistic expressions was performed using the scale shown in Figure 6. The display of the obtained values is given in Table 12.

Table 12

Fuzzified initial decision matrix by application of $\mathrm{Z}$ numbers in the ranking of alternatives

\begin{tabular}{|c|c|c|c|c|c|c|c|c|c|c|}
\hline \multirow{2}{*}{ Alternative } & \multirow{2}{*}{$\begin{array}{c}\text { Alter- } \\
\text { native } \\
\text { index }\end{array}$} & \multirow{2}{*}{$\mathrm{C}_{1}$} & \multirow{2}{*}{$\mathrm{C}_{2}$} & \multicolumn{2}{|l|}{$\mathrm{C}_{3}$} & \multicolumn{2}{|l|}{$\mathrm{C}_{4}$} & \multirow{2}{*}{$\mathrm{C}_{5}$} & \multicolumn{2}{|l|}{$\mathrm{C}_{6}$} \\
\hline & & & & $\tilde{\mathrm{A}}$ & $\tilde{\mathrm{B}}$ & $\tilde{\mathrm{A}}$ & $\tilde{\mathrm{B}}$ & & $\tilde{\mathrm{A}}$ & $\tilde{\mathrm{B}}$ \\
\hline $\mathrm{B} \log \mathrm{s}$ & $\mathrm{A}_{1}$ & 5 & 4 & $(45,50,55)$ & 0.067 & $(4.5,5,5)$ & 0.25 & 0.1 & $(2.5,3,3.5)$ & 0.25 \\
\hline Facebook & $\mathrm{A}_{2}$ & 7 & 5 & $(85,90,95)$ & 0.25 & $(3.5,4,4.5)$ & 0.75 & 1721 & $(4.5,5,5)$ & 0.25 \\
\hline Youtube & $\mathrm{A}_{3}$ & 4 & 3 & $(90,95,100)$ & 0.5 & $(3.5,4,4.5)$ & 0.933 & 1325 & $(2.5,3,3.5)$ & 0.933 \\
\hline Twitter & $\mathrm{A}_{4}$ & 5 & 4 & $(28,33,38)$ & 0.5 & $(3.5,4,4.5)$ & 0.5 & 342 & $(3.5,4,4.5)$ & 0.5 \\
\hline LinkedIn & $\mathrm{A}_{5}$ & 3 & 3 & $(29,34,40)$ & 0.067 & $(3.5,4,4.5)$ & 0.25 & 380 & $(1.5,2,2.5)$ & 0.067 \\
\hline Pinterest & $\mathrm{A}_{6}$ & 5 & 3 & $(22,27,32)$ & 0.933 & $(2.5,3,3.5)$ & 0.933 & 73 & $(3.5,4,4.5)$ & 0.75 \\
\hline Flicker & $\mathrm{A}_{7}$ & 4 & 3 & $(7,12,17)$ & 0.75 & $(2.5,3,3.5)$ & 0.5 & 120 & $(2.5,3,3.5)$ & 0.5 \\
\hline Instagram & $\mathrm{A} 8$ & 7 & 3 & $(81,86,91)$ & 0.5 & $(2.5,3,3.5)$ & 0.067 & 500 & $(4.5,5,5)$ & 0.067 \\
\hline Wikipedia & $\mathrm{A}_{9}$ & 1 & 1 & $(51,56,61)$ & 0.933 & $(1.5,2,2.5)$ & 0.067 & 1500 & $(1,1,1)$ & 0.75 \\
\hline Vimeo & $\mathrm{A}_{10}$ & 4 & 3 & $(0,4,9)$ & 0.25 & $(3.5,4,4.5)$ & \begin{tabular}{|l|}
0.75 \\
\end{tabular} & 40 & $(2.5,3,3.5)$ & 0.933 \\
\hline
\end{tabular}

Using the expression for transferring Z-numbers into standard fuzzy numbers, a new fazified initial matrix of decision-making is obtained, Table 13. 
Table 13

Fuzzified initial matrix of decision making using classic fuzzy numbers

\begin{tabular}{|c|c|c|c|c|c|c|c|}
\hline Alternative & $\begin{array}{c}\text { Alternative } \\
\text { index }\end{array}$ & $\mathrm{C}_{1}$ & $\mathrm{C}_{2}$ & $\mathrm{C}_{3}$ & $\mathrm{C}_{4}$ & $\mathrm{C}_{5}$ & $\mathrm{C}_{6}$ \\
\hline $\mathrm{B} \log s$ & $\mathrm{~A}_{1}$ & 5 & 4 & $\begin{array}{c}(0.904,1.033 \\
1.162)\end{array}$ & $\begin{array}{c}(2.25,2.5 \\
2.5)\end{array}$ & 0.1 & $\begin{array}{c}(1.25,1.5 \\
1.75)\end{array}$ \\
\hline Facebook & $\mathrm{A}_{2}$ & 7 & 5 & $\begin{array}{c}(2.25,2.5 \\
2.5)\end{array}$ & $\begin{array}{c}(3.031,3.464, \\
3.897)\end{array}$ & 1721 & $\begin{array}{c}(2.25,2.5 \\
2.5)\end{array}$ \\
\hline Youtube & $\mathrm{A}_{3}$ & 4 & 3 & $\begin{array}{c}(1.768,2.121 \\
2.475) \\
\end{array}$ & $\begin{array}{c}(3.381,3.864 \\
4.347) \\
\end{array}$ & 1325 & $\begin{array}{c}(2.415,2.898, \\
3.381)\end{array}$ \\
\hline Twitter & $\mathrm{A}_{4}$ & 5 & 4 & $\begin{array}{c}(2.475,2.828 \\
3.182) \\
\end{array}$ & $\begin{array}{c}(2.475,2.828, \\
3.182) \\
\end{array}$ & 342 & $\begin{array}{c}(2.475,2.828, \\
3.182) \\
\end{array}$ \\
\hline LinkedIn & $\mathrm{A}_{5}$ & 3 & 3 & $\begin{array}{c}(0.904,1.033 \\
1.162)\end{array}$ & $(1.75,2,2.25)$ & 380 & $\begin{array}{c}(0.387,0.516, \\
0.645)\end{array}$ \\
\hline Pinterest & $\mathrm{A}_{6}$ & 5 & 3 & $\begin{array}{c}(2.415,2.898 \\
3.381) \\
\end{array}$ & $\begin{array}{c}(2.415,2.898 \\
3.381) \\
\end{array}$ & 73 & $\begin{array}{c}(3.031,3.464, \\
3.897)\end{array}$ \\
\hline Flicker & $\mathrm{A}_{7}$ & 4 & 3 & $\begin{array}{c}(2.165,2.598 \\
3.031) \\
\end{array}$ & $\begin{array}{c}(1.768,2.121, \\
2.475)\end{array}$ & 120 & $\begin{array}{c}(1.768,2.121, \\
2.475)\end{array}$ \\
\hline Instagram & $\mathrm{A}_{8}$ & 7 & 3 & $\begin{array}{c}(1.768,2.121 \\
2.475) \\
\end{array}$ & $\begin{array}{c}(0.645,0.775 \\
0.904) \\
\end{array}$ & 500 & $\begin{array}{c}(0.904,1.033, \\
1.162) \\
\end{array}$ \\
\hline Wikipedia & A9 & 1 & 1 & $\begin{array}{c}(0.966,0.966 \\
0.387)\end{array}$ & $\begin{array}{c}(0.387,0.516 \\
0.645)\end{array}$ & 1500 & $\begin{array}{c}(0.866,0.866, \\
0.866)\end{array}$ \\
\hline Vimeo & $\mathrm{A}_{10}$ & 4 & 3 & $(1.25,1.5,1.75)$ & $\begin{array}{c}(3.031,3.464, \\
3.897)\end{array}$ & 40 & $\begin{array}{c}(2.415,2.898, \\
3.381\end{array}$ \\
\hline
\end{tabular}

After defining the initial decision matrix with standard fuzzy numbers, the application of the fuzzy MABAC method is performed. The final rank of the alternative is shown in Table 14.

Table14

Final rang of alternatives

\begin{tabular}{|c|c|c|c|c|c|c|}
\hline Alternative & $\begin{array}{c}\text { Altern. } \\
\text { index. }\end{array}$ & $\begin{array}{c}\text { Defuzzification } \\
\tilde{\mathrm{w}}_{1 \mathrm{j}} \text { applying } \\
\text { expression 4 }\end{array}$ & $\begin{array}{c}\text { Defuzzification } \\
\tilde{\mathrm{w}}_{1 \mathrm{j}} \text { applying } \\
\text { expression 5, } \\
\lambda=0\end{array}$ & $\begin{array}{c}\text { Defuzzification } \\
\tilde{\mathrm{w}}_{1 \mathrm{j}} \text { applying } \\
\text { expression 5, } \\
\lambda=0.5\end{array}$ & $\begin{array}{c}\text { Defuzzification } \\
\tilde{\mathrm{w}}_{1 \mathrm{j}} \text { applying } \\
\text { expression 5, } \\
\lambda=1\end{array}$ & Rank \\
\hline Blogs & $\mathrm{A}_{1}$ & -0.063 & -0.072 & -0.063 & -0.055 & 6 \\
\hline Facebook & $\mathrm{A}_{2}$ & 0.476 & 0.467 & 0.477 & 0.486 & 1 \\
\hline Youtube & $\mathrm{A}_{3}$ & 0.182 & 0.164 & 0.181 & 0.199 & 2 \\
\hline Twitter & $\mathrm{A}_{4}$ & 0.084 & 0.069 & 0.084 & 0.098 & 4 \\
\hline LinkedIn & $\mathrm{A}_{5}$ & -0.169 & -0.177 & -0.169 & -0.161 & 10 \\
\hline Pinterest & $\mathrm{A}_{6}$ & 0.024 & 0.005 & 0.023 & 0.042 & 5 \\
\hline Flicker & $\mathrm{A}_{7}$ & -0.079 & -0.095 & -0.080 & -0.064 & 8 \\
\hline
\end{tabular}




\begin{tabular}{|c|c|c|c|c|c|c|}
\hline Instagram & $\mathrm{A}_{8}$ & 0.104 & 0.094 & 0.104 & 0.114 & 3 \\
\hline Wikipedia & $\mathrm{A}_{9}$ & -0.157 & -0.161 & -0.157 & -0.153 & 9 \\
\hline Vimeo & $\mathrm{A}_{10}$ & -0.079 & -0.095 & -0.079 & -0.064 & 7 \\
\hline
\end{tabular}

Regardless of which model of defadification is taken, the ranking alternative has not changed. However, a deeper analysis suggests that there are differences from one to another defadification, and that under certain circumstances the ranking of the alternative could be altered, primarily when it comes to the close values of the output parameters. The ranking of the first four alternatives were approved by the experts, who were interviewed independently of the application of the method. Matching expert views suggest that the model accurately depicts real world. On the other hand, the significance of the model is reflected in the ranking of other alternatives, as for other alternatives experts had very different views.

An unavoidable step in modeling is the assessment of its sensitivity. The sensitivity assessment was done by changing the weight coefficients of the criteria, using different scenarios, wherein each scenario the second criterion was favorable [62]. The display of weight coefficients according to the scenarios is given in Table 15.

\section{Table 15}

Weight coefficient in a different scenario

\begin{tabular}{|c|c|c|c|c|c|c|c|}
\hline Criterion & $\mathrm{S}_{0}$ & $\mathrm{~S}_{1}$ & $\mathrm{~S}_{2}$ & $\mathrm{~S}_{3}$ & $\mathrm{~S}_{4}$ & $\mathrm{~S}_{5}$ & $\mathrm{~S}_{6}$ \\
\hline $\mathrm{C}_{1}$ & 0.351 & 0.5 & 0.1 & 0.1 & 0.1 & 0.1 & 0.1 \\
\hline $\mathrm{C}_{2}$ & 0.113 & 0.1 & 0.5 & 0.1 & 0.1 & 0.1 & 0.1 \\
\hline $\mathrm{C}_{3}$ & 0.063 & 0.1 & 0.1 & 0.5 & 0.1 & 0.1 & 0.1 \\
\hline $\mathrm{C}_{4}$ & 0.074 & 0.1 & 0.1 & 0.1 & 0.5 & 0.1 & 0.1 \\
\hline $\mathrm{C}_{5}$ & 0.318 & 0.1 & 0.1 & 0.1 & 0.1 & 0.5 & 0.1 \\
\hline $\mathrm{C}_{6}$ & 0.081 & 0.1 & 0.1 & 0.1 & 0.1 & 0.1 & 0.5 \\
\hline
\end{tabular}

The values obtained by applying different scenarios are given in Table 16 .

Table 16

Ranking of alternatives by applying different scenarios

\begin{tabular}{|c|c|c|c|c|c|c|c|c|c|c|c|c|c|c|}
\hline \multirow{2}{*}{$\begin{array}{c}\text { Altern. } \\
\text { index }\end{array}$} & \multicolumn{2}{|l|}{$\mathrm{S}_{0}$} & \multicolumn{2}{|l|}{$\mathrm{S}_{1}$} & \multicolumn{2}{|l|}{$\mathrm{S}_{2}$} & \multicolumn{2}{|l|}{$\mathrm{S}_{3}$} & \multicolumn{2}{|l|}{$\mathrm{S}_{4}$} & \multicolumn{2}{|l|}{$\mathrm{S}_{5}$} & \multicolumn{2}{|l|}{$\mathrm{S}_{6}$} \\
\hline & W & $\left|\begin{array}{l}\mathrm{ra}- \\
\mathrm{nk}\end{array}\right|$ & W & nk & W & $\begin{array}{l}\text { ra- } \\
\text { nk }\end{array}$ & W & $\left|\begin{array}{l}\mathrm{ra}- \\
\mathrm{nk}\end{array}\right|$ & W & $\begin{array}{l}\text { ra- } \\
\text { nk }\end{array}$ & W & $\begin{array}{l}\mathrm{ra}- \\
\mathrm{nk}\end{array}$ & W & $\begin{array}{l}\text { ra- } \\
\text { nk }\end{array}$ \\
\hline $\mathrm{A}_{1}$ & -0.063 & 6 & 0.002 & 6 & 0.046 & 5 & -0.178 & 8 & -0.034 & 7 & -0.164 & 10 & -0.094 & 7 \\
\hline $\mathrm{A}_{2}$ & 0.476 & 1 & 0.402 & 1 & 0.413 & 1 & 0.312 & 1 & \begin{tabular}{|l}
0.339 \\
\end{tabular} & 1 & 0.503 & 1 & \begin{tabular}{|l}
0.277 \\
\end{tabular} & 1 \\
\hline $\mathrm{A}_{3}$ & 0.182 & 2 & 0.091 & 5 & 0.102 & 3 & 0.154 & 4 & 0.268 & 2 & 0.300 & 2 & 0.221 & 3 \\
\hline $\mathrm{A}_{4}$ & 0.084 & 4 & 0.143 & 3 & 0.187 & 2 & 0.253 & 2 & 0.149 & 3 & 0.056 & 4 & 0.198 & 4 \\
\hline A5 & -0.169 & 10 & -0.206 & 9 & -0.128 & 9 & -0.253 & 9 & -0.150 & 8 & -0.150 & 9 & -0.281 & 9 \\
\hline $\mathrm{A}_{6}$ & 0.024 & 5 & 0.125 & 4 & 0.069 & 4 & 0.246 & 3 & \begin{tabular}{|l}
0.138 \\
\end{tabular} & 4 & -0.024 & 6 & 0.252 & 2 \\
\hline
\end{tabular}




\begin{tabular}{|c|c|c|c|c|c|c|c|c|c|c|c|c|c|c|}
\hline $\mathrm{A}_{7}$ & -0.079 & 8 & -0.026 & 8 & -0.015 & 7 & 0.114 & 5 & -0.025 & 6 & -0.097 & 7 & 0.015 & 6 \\
\hline $\mathrm{A}_{8}$ & 0.104 & 3 & 0.162 & 2 & -0.027 & 8 & 0.025 & 6 & -0.173 & 9 & -0.021 & 5 & -0.121 & 8 \\
\hline $\mathrm{A}_{9}$ & -0.157 & 9 & -0.388 & 10 & -0.377 & 10 & -0.312 & 10 & -0.349 & 10 & 0.061 & 3 & -0.290 & 10 \\
\hline $\mathrm{A}_{10}$ & -0.079 & 7 & -0.019 & 7 & -0.008 & 6 & -0.056 & 7 & 0.118 & 5 & -0.109 & 8 & 0.111 & 5 \\
\hline
\end{tabular}

By analyzing the obtained results, it can be determined that there are differences in ranks when applying different scenarios, which indicates that the model is sensitive to changes. It is noted that alternative A2 is always ranked as the first one, which can indicate the insensitivity of the model, but the specific values of the output results are in favor of the sensitivity of the system. In support of this, the results obtained with scenario number 6 , where the values of the first three ranged alternatives are very close. A constant rank of Alternative A2 indicates the dominance of the input parameters of this alternative relative to others by all criteria. The highest ranking range is present in the alternative A8, where the ranges go from 2 to 9 , and alternatives A9 where the ranges go from 3 to 10 . In other alternatives, this ranking range is much lower. All of the above indicates that the model can tolerate even minor errors in defining the weight coefficients of the criteria.

For the mathematical determination of the correlation of ranks, the values of Spirman's coefficient were used:

$S=1-\frac{6 \sum_{i=1}^{n} D_{i}^{2}}{n\left(n^{2}-1\right)}$

where is:

$S$ - the value of the Spirman coefficient,

$D i$ - the difference in the rank of the given element in the vector $\mathrm{w}$ and the rank of the correspondent element in the reference vector, $n$ - the number of ranked elements.

The rank of each criterion - the alternative is determined based on the weight coefficient vector $w=\left(w_{1}, w_{2}, \ldots, w_{n}\right)$.

Spirman's coefficient takes values from the interval $[-1,1]$. When the ranks of the elements completely coincide, the Spirman coefficient is 1 ("ideal positive correlation"). When the ranks are completely opposite, the Spirman coefficient is 1 ("ideal negative correlation"), that is, when $\mathrm{S}=0$ the ranks are unregulated.

Table 17

Spirman's coefficient values

\begin{tabular}{|c|c|c|c|c|c|c|c|}
\hline & $\mathrm{S}_{0}$ & $\mathrm{~S}_{1}$ & $\mathrm{~S}_{2}$ & $\mathrm{~S}_{3}$ & $\mathrm{~S}_{4}$ & $\mathrm{~S}_{5}$ & $\mathrm{~S}_{6}$ \\
\hline $\mathrm{S}_{0}$ & - & 0.915 & 0.782 & 0.782 & 0.685 & 0.636 & 0.721 \\
\hline $\mathrm{S}_{1}$ & - & - & 0.733 & 0.806 & 0.588 & 0.455 & 0.673 \\
\hline
\end{tabular}




\begin{tabular}{|c|c|c|c|c|c|c|c|}
\hline $\mathrm{S}_{2}$ & - & - & - & 0.879 & 0.939 & 0.418 & 0.915 \\
\hline $\mathrm{S}_{3}$ & - & - & - & - & 0.867 & 0.539 & 0.903 \\
\hline $\mathrm{S}_{4}$ & - & - & - & - & - & 0.455 & 0.952 \\
\hline $\mathrm{S}_{5}$ & - & - & - & - & - & - & 0.430 \\
\hline $\mathrm{S}_{6}$ & - & - & - & - & - & - & - \\
\hline
\end{tabular}

As seen from the table of Spirman's coefficient values, they are very high in a large number of cases. It can be said that there are no unordered ranks, which leads to the same conclusion as after the analysis of the previous picture, i.e., that the model can tolerate even minor errors in defining the weight coefficients of the criteria.

\section{Conclusion}

The Ministry of Defense of the Republic of Serbia uses a criteria selection and ranking methodology in choosing the social media platforms it uses in communication with the public. Statistical indicators and analyses of the usage of social media by the public administration of the Republic of Serbia, which are conducted annually by the Office for Electronic Administration of the Republic of Serbia and the Faculty of Organizational Sciences of the University of Belgrade [63], identify the Ministry of Defense as the most efficient governmental institution in the application of social media.

Further development of social media ranking methodology can be articulated in two directions: Firstly, the development of an application using set criteria and weight factors for automatic ranking according to the described methodology, thus speeding up data calculation and giving the experts the opportunity to correct errors in criteria and weight factors assessment. Secondly, the selection process and the number of criteria affecting ranking can be further improved in direct dependence on future development and usage of social media on a global level.

\section{Literature}

[1] K. H. Yoo, R. J. Kim: Review How U. S. state tourism offices use online newsrooms and social media in media relations, Public Relations Review, Vol. 39, 2013, pp. 534-541

[2] R. Medaglia, L. Zheng: Mapping government social media research and moving it forward: A framework and a research agenda, Government Information Quarterly, 2017, Vol. 34, pp. 496-510

[3] J. Kietzmann, et al.: Social media? Get serious! Understanding the functional building blocks of social media, Business Horizons, 2011, Vol. 54, pp. 241-251

[4] T. M. Nisar, G. Prabhakar, L. Strakova: Social media information benefits, knowledge management and smart organizations, Journal of Business Research, 2019, Vol. 94, pp. 264-272 
[5] T. Grizane, I. Jurgelane: Social media impact on Bussiness Evaluation, Procedia Computer Science, 2017, Vol. 104, pp. 190-196

[6] J. I. Criado, J. Villodre: Public employees in social media communities: Exploring factors for internal collaboration using social network analysis, First Monday, 2018, Vol. 23, No. 4

[7] G. F. Khan, H. Y. Yoon, H. W. Park: "Social media use in the public sector: a comparative study of the Korean \& US Government", The $8^{\text {th }}$ International Conference on Webometrics, Informatics and Scientometrics $\& 13^{\text {th }}$ COLLNET Meeting, 2012, Seoul

[8] R. S. Almazan, J. R. Gil-Garcia: Are government internet portals evolving towards more interaction, participation, and collaboration? Revisiting the rhetoric of e-government among municipalities, Government Information Quarterly, 2012, Vol. 29, pp. 72-81

[9] A. Zerfass, D. M. Schramm: Review Social Media Newsrooms in public relations: A conceptual framework and corporate practices in three countries, Public Relation Review, 2014, Vol. 40, pp. 79-91

[10] A. J. Meijer, R. Tolenvlied: Social Media and the New Organization of Government Communications: An Empirical Analysis of Twitter Usage by the Dutch Police, American Review of Public Administration, 2016, Vol. 46, pp. 143-161

[11] R. Dilenschneider: The AMA Handbook of Public Relations, Amacom, 2010

[12] C. Knox: Public Administrators Use of Social Media Platforms: Overcoming the Legitimacy Dilemma, Administration and Society, 2014, Vol. 48, pp. 477-496

[13] M. Feeney, E Welch: Technology - Task Coupling: Exploring Social Media Use and Managerial Perceptions of E-government, American Review of Public Administration, 2016, Vol. 46, pp. 162-179

[14] J. Kietzmann, et al.: Social media? Get serious! Understanding the functional building blocks of social media, Business Horizons, 2011, Vol. 54, pp. 241-251

[15] https://www.alexa.com/topsites/countries, Date: 30.06.2019

[16] A. Kaplan, M. Haenlein, Users of the world, unite! The challenges and opportunities of Social Media, Business Horizons, 2010, 53, pp. 59-68

[17] R. L. Daft, R. H. Lengel: Information Richness: A New Approach to Managerial Behaviour and Organizational Design. In Research in Organizational Behaviour, CT JAI Press, 1984

[18] A. Drobnjak, Fuzzy Social Media Clustering, Master thesis, University of Fribourg, Switzerland, 2012 
[19] K. Djuric-Atanasievski, Z. Bobar: Social Media and Public Sector - The experience of the use of Social Media in State Organizations and Serbian Defense Structure, Symorg, Zlatibor, 2016, Vol. 15, pp. 125-133

[20] M. Cho, T. Schweickart, T. Haase: Public engagement with nonprofit organizations on Facebook, Public Relation Review, 2014, Vol. 40, pp. $565-567$

[21] T. L. Saaty: The analytic hierarchy process, McGraw-Hill, New York, 1980

[22] L. A. Zadeh: A Rationale for Fuzzy Control, Journal of Dynamic Systems, Measurement and Control, 1972, Vol. 94, pp. 3-4

[23] L. A. Zadeh: Outline of a new approach to the analysis of complex systems and decision processes, IEEE Transactions on Systems, Man and Cybernetics, 1973, SMC-3(1), pp. 28-44

[24] L. Zadeh: Fuzzy sets, Information and control, 1965, Vol. 8, pp. 338-353

[25] D. Pamucar, D. Bozanic, A. Milic: „Selection of a course of action by Obstacle Employment Group based on a fuzzy logic system“, YUJOR, 2016, Vol. 26, pp. 75-90, doi: 10.2298/YJOR140211018P

[26] K. Husain, M. Rashid, N. Vitkovic, J. Mitic, J. Milovanovic, M. Stojkovic: Geometrical models of mandible fracture and plate implant, Facta Universitatis, Series: Mechanical Engineering, 2018, 16(2), pp. 369-379

[27] L. M. Seiford: The evolution of the state-of-art (1978-1995), Journal of Productivity Analysis, 1996, Vol. 7, pp. 99-137

[28] T. S. Liou, M. J. Wang: Ranking fuzzy numbers with integral value. Fuzzy Sets and Systems, 1992, Vol. 50, pp. 247-256

[29] M. Milicevic: The Expert Evaluation, MC „Defense“, Belgrade, 2014

[30] D. Bozanic, D. Pamucar, D. Bojanic: „Modification of the Analytic Hierarchy Proces (AHP) Method using fuzzy logic: fuzzy AHP approach as a support to the decision making process concerning engagement of the Group for Additional Hindering“, Serbian Journal of Management, 2015, Vol. 10, pp. 151-171

[31] D. Pamucar, D. Bozanic, V. Lukovac, N. Komazec: Normalized weighted geometric bonferroni mean operator of interval rough numbers application in interval rough DEMATEL-COPRAS. Facta Universitatis, Series: Mechanical Engineering, 2018, Vol. 16, pp. 171-191

[32] F. T. Bozbura, A. Beskese, C. Kahraman: Prioritization of human capital measurement indicators using fuzzy AHP, Expert Systems with Applications, 2007, Vol. 32, pp. 1100-1112

[33] M. T. Isaai, A. Kanani, M. Tootoonchi, H. R. Afzali: Intelligent timetable evaluation using fuzzy AHP, Expert Systems with Applications, 2011, Vol. 38, pp. 3718-3723 
[34] K. Mandic, B. Delibasic, S. Knezevic, S. Benkovic: Analysis of the financial parameters of Serbian banks through the application of the fuzzy AHP and TOPSIS methods. Economic Modelling, 2014, Vol. 43, pp. 30-37

[35] F. R. L. Junior, L. Osiro, L. C. R. Carpinetti: A comparison between Fuzzy AHP and Fuzzy TOPSIS methods to supplier selection, Applied Soft Computing, 2014, Vol. 21, pp. 194-209

[36] A. Ruiz-Padillo, A. J. Torija, A. F. Ramos-Ridao, D. P. Ruiz: Application of the fuzzy analytic hierarchy process in multi-criteria decision in noise action plans: Prioritizing road stretches, Environmental Modelling \& Software, 2016, Vol. 81, pp. 45-55

[37] B. Srdjevic, Y. Dantas, P. Modeiros: Fuzzy AHP Assessment of Water Management Plans, Water Resour Manage, 2008, Vol. 22, pp. 877-894

[38] V. Nikolic, M. Milovancevic, D. Petkovic, D. Jocic, M. Savic: Parameters forecasting of laser welding by the artificial intelligence techniques, Facta Universitatis, Series: Mechanical Engineering, 2018, Vol. 16, pp. 193-201

[39] D. Pamučar, V. Lukovac, D. Božanić, N. Komazec: Multi-criteria FUCOM-MAIRCA model for the evaluation of level crossings: case study in the Republic of Serbia, Operational Research in Engineering Sciences: Theory and Applications, 2018, Vol. 1, pp. 108-129

[40] L. Abdullah, L. Najib: A new type-2 fuzzy set of linguistic variables for the fuzzy analytic hierarchy process. Expert Systems with Applications, 2014, Vol. 41, pp. 3297-3305

[41] C. Kahraman, B. Öztayşi, I.U. Sari, E. Turanoğu: Fuzzy analytic hierarchy process with interval type-2 fuzzy sets. Knowledge-Based Systems, 2014, Vol. 59, pp. 48-57

[42] D. Pamucar, G. Cirovic, D. Sekulovic: Development of an integrated transport system in distribution centers: A FA'WOT analysis, Technical Gazzete, 2015, Vol. 22, pp. 649-658

[43] D. Bozanic, D. Pamucar, D. Bojanic: „Modification of the Analytic Hierarchy Proces (AHP) Method using fuzzy logic: fuzzy AHP approach as a support to the decision making process concerning engagement of the Group for Additional Hindering“, Serbian Journal of Management, 2015, Vol. 10, pp. 151-171

[44] D. Bozanic, D. Pamucar, S. Karovic: Use of the fuzzy AHP - MABAC hybrid model in ranking potential locations for preparing laying-up positions, Military Technical Courier, 2016, Vol. 64, pp. 705-729, doi: 10.5937/vojtehg64-9261

[45] D. Pamucar, D. Bozanic, D. Kurtov: Fuzzification of the Saaty's scale and a presentation of the hybrid fuzzy AHP-TOPSIS model: an example of the selection of a brigade artillery group firing position in a defensive 
operation, Military Technical Courier, 2016, Vol. 64 (4), pp. 966-986, doi: 10.5937/vojtehg64-9262

[46] D. Bozanic, D. Tesic, J. Milicevic: A hybrid fuzzy AHP-MABAC model: Application in the Serbian Army - the selection of the location for deep wading as a technique of crossing the river by tanks, Decision Making: Applications in Management and Engineering, 2018, Vol. 1, pp. 143-164

[47] D. Bojanic, M. Kovac, M. Bojanic, V. Ristic: Multi-criteria decisionmaking in A defensive operation of THE Guided anti-tank missile battery: an example of the hybrid model fuzzy AHP - MABAC, Decision Making: Applications in Management and Engineering, 2018, Vol. 1, pp. 51-66

[48] L. A. Zadeh: A note on Z-number, Information Sciences, 2011, Vol. 181, pp. 2923-2932

[49] B. Kang, D. Wei, Y. Li, Y. Deng: Decision Making Using Z-numbers under Uncertain Environment, Journal of Computational Information Systems, 2012, Vol. 8, pp. 2807-2814

[50] B. Kang, D. Wei, Y. Li, Y. Deng: A Method of Converting Z-number to Classical Fuzzy Number, Journal of Information \& Computational Science, 2012, Vol. 9 (3), pp. 703-709

[51] R. A. Krohling, G. Artem dos Santos, A. G. C. Pacheco: TODIM and TOPSIS with Z-number, arxiv.org/pdf/1609.05705

[52] N. A. Sahrom, R. M. Dom: A Z-number extension of the hybrid Analytic Hierarchy Process-Fuzzy Data Envelopment Analysis for risk assessment. In ICREM7 - Proceedings of the $7^{\text {th }}$ International Conference on Research and Education in Mathematics: Empowering Mathematical Sciences through Research and Education, Kuala Lumpur, Malaysia, 2015, pp. 1924, doi: 10.1109/ICREM.2015.7357019

[53] A. Azadeh, R. Kokabi: Z-number DEA: A new possibilistic DEA in the context of Z-numbers, Advanced Engineering Informatics, 2016, Vol. 30, pp. $604-617$

[54] A. Azadeh, M. Saberi, P. Pazhoheshfar: Z-AHP: A Z-number Extension of Fuzzy Analytical Hierarchy Process (2013) $7^{\text {th }}$ IEEE International Conference on Digital Ecosystems and Technologies (DEST), pp. 141-147

[55] A. M. Yaakob, A. Gegov: Fuzzy Rule-Based Approach with Z-Numbers for Selection of Alternatives using TOPSIS, IEEE International Conference on Fuzzy Systems At Istanbul, Turkey, 2015, pp. 1-8

[56] M. Ciavarella, G. Carbone, V. Vinogradov: A critical assessment of Kassapoglou's statistical model for composites fatigue, Facta Universitatis, Series: Mechanical Engineering, 2018, Vol. 16, 115-126 
[57] R. Chutia, S. Mahanta, D. Datta: Linear equations of generalized triangular fuzzy numbers, Annals of Fuzzy Mathematics and Informatics, 2013, Vol. 6 (2), pp. 371-376

[58] R. Saneifard: On The Ranking Fuzzy Numbers Using Signal/Noise Ratios, Int. J. Industrial Mathematics, 2015, Vol. 7 (1), pp. 213-219

[59] H. J. Zimmermann: Fuzzy Set Theory and It's Applications, Second Revised ed., Kluwer Academic Publishers, Boston/Dordrecht/London, 1991

[60] D. Pamucar, D. Cirovic: The selection of transport and handling resources in logistics centers using Multi-Attributive Border Approximation area Comparison (MABAC), Expert systems with applications, 2015, Vol. 42(6), pp. 3016-3028

[61] Z. Nunić: Evaluation and selection of the PVC carpentry manufacturer using the FUCOM-MABAC model, Operational Research in Engineering Sciences: Theory and Applications, 2018, Vol. 1 (1), pp. 13-28

[62] D. Pamucar, D. Bozanic, A. Randjelovic: Multi-criteria decision making: An example of sensitivity analysis, Serbian Journal of Management, 2017, Vol. 12(1), pp. 1-27, DOI:10.5937/sjm12-9464

[63] [http://www.deu.gov.rs/latinica/dokumenti.php Date: 15.08.2018 